\title{
Article \\ Production of Recombinant Human Ceruloplasmin: Improvements and Perspectives
}

\author{
Maria Carmela Bonaccorsi di Patti ${ }^{1, *} \mathbb{1}$, Antimo Cutone ${ }^{2} \mathbb{1}$, Marek Nemčovič ${ }^{3}$, Zuzana Pakanová ${ }^{3}(\mathbb{D}$, \\ Peter Baráth ${ }^{3}$ (D) and Giovanni Musci ${ }^{2, *(D)}$ \\ 1 Department of Biochemical Sciences 'A. Rossi Fanelli', Sapienza University of Rome, 00185 Rome, Italy \\ 2 Department Biosciences and Territory, University of Molise, 86090 Pesche, Italy; antimo.cutone@unimol.it \\ 3 Institute of Chemistry, Slovak Academy of Sciences, 84538 Bratislava, Slovakia; \\ marek.nemcovic@savba.sk (M.N.); zuzana.pakanova@savba.sk (Z.P.); peter.barath@savba.sk (P.B.) \\ * Correspondence: mariacarmela.bonaccorsi@uniroma1.it (M.C.B.d.P.); giovanni.musci@unimol.it (G.M.)
}

check for updates

Citation: Bonaccorsi di Patti, M.C. Cutone, A.; Nemčovič, M.; Pakanová, Z.; Baráth, P.; Musci, G. Production of Recombinant Human Ceruloplasmin: Improvements and Perspectives. Int. J. Mol. Sci. 2021, 22, 8228. https:// doi.org/10.3390/ijms22158228

Academic Editor: Rosanna Squitti

Received: 22 June 2021

Accepted: 28 July 2021

Published: 30 July 2021

Publisher's Note: MDPI stays neutral with regard to jurisdictional claims in published maps and institutional affiliations.

Copyright: (c) 2021 by the authors. Licensee MDPI, Basel, Switzerland. This article is an open access article distributed under the terms and conditions of the Creative Commons Attribution (CC BY) license (https:// creativecommons.org/licenses/by/ $4.0 /)$.

\begin{abstract}
The ferroxidase ceruloplasmin (CP) plays a crucial role in iron homeostasis in vertebrates together with the iron exporter ferroportin. Mutations in the CP gene give rise to aceruloplasminemia, a rare neurodegenerative disease for which no cure is available. Many aspects of the (patho)physiology of CP are still unclear and would benefit from the availability of recombinant protein for structural and functional studies. Furthermore, recombinant $\mathrm{CP}$ could be evaluated for enzyme replacement therapy for the treatment of aceruloplasminemia. We report the production and preliminary characterization of high-quality recombinant human CP in glycoengineered Pichia pastoris SuperMan5. A modified yeast strain lacking the endogenous ferroxidase has been generated and employed as host for heterologous expression of the secreted isoform of human CP. Highly pure biologically active protein has been obtained by an improved two-step purification procedure. Glycan analysis indicates that predominant glycoforms HexNAc2Hex8 and HexNAc2Hex11 are found at Asn119, Asn378, and Asn743, three of the canonical four N-glycosylation sites of human CP. The availability of high-quality recombinant human $\mathrm{CP}$ represents a significant advancement in the field of $\mathrm{CP}$ biology. However, productivity needs to be increased and further careful glycoengineering of the SM5 strain is mandatory in order to evaluate the possible therapeutic use of the recombinant protein for enzyme replacement therapy of aceruloplasminemia patients.
\end{abstract}

Keywords: ceruloplasmin; ferroxidase; Pichia pastoris; glycoengineered yeast; iron; copper; aceruloplasminemia

\section{Introduction}

The ferroxidase ceruloplasmin (CP) belongs to the family of the blue multicopper oxidases, characterized by the presence of multiple copper ions, which safely couple the oxidation of substrates to the controlled reduction of oxygen to water without release of potentially toxic intermediates [1,2]. CP is a large multi-domain glycoprotein made up of six cupredoxin domains arranged with a ternary pseudosymmetry. The interface between domains 1 and 6 hosts the catalytically essential trinuclear copper cluster formed by type 2 and type 3 binuclear copper where oxygen is reduced to water. Domains 2, 4, and 6 each harbor a type 1 copper site, where electrons are accepted from the substrate. Two isoforms of CP are found in mammals: secreted CP is mainly synthesized by hepatocytes and released into the plasma, while a GPI-anchored form (CP-GPI) produced by alternative splicing has been identified prevalently in the brain but also in other cell types [3]. Several functions have been attributed to $\mathrm{CP}$, ranging from copper transport to ferrous iron and biological amines oxidation, as well as antioxidant activity via prevention of the formation of free radicals through different mechanisms, but it is now widely accepted that the main physiological role of $\mathrm{CP}$ is related to its ferroxidase activity [3,4]. Export of ferrous iron from cells is mediated by ferroportin, the only known mammalian iron exporter; iron is 
then oxidized by a ferroxidase to facilitate safe loading onto transferrin for distribution throughout the body [5-7]. Depending on the cell type, the ferroxidase activity is provided either by CP (soluble or GPI-linked) or by hephaestin, a multicopper oxidase involved in intestinal iron absorption [8] and iron efflux in neurons [9]. The connection between ferroxidases and ferroportin is further strengthened by the finding that the ferroxidase activity of $\mathrm{CP}$ or of hephaestin is required for the stability of cell surface ferroportin and the transporter is rapidly internalized and degraded in the absence of the ferroxidase [10,11].

Aceruloplasminemia is a rare genetic disease caused by mutations in the gene of CP $[12,13]$. Approximately 70 mutations of the CP gene have been described mainly in Japanese and Caucasian patients [14-16]. Patients develop retinal degeneration, diabetes mellitus, and neurologic symptoms, which include ataxia, involuntary movements, parkinsonism, mood and behavior disturbances, and cognitive impairment [17]. Characterization of aceruloplasminemia missense mutants has indicated that most mutants lacked ferroxidase activity either due to retention in the endoplasmic reticulum (ER) or to production as apo-CP lacking copper, owing to folding defects $[14,18,19]$. However, other mutants were partly or fully functional $[20,21]$, indicating that our understanding of the pathogenesis of aceruloplasminemia is still incomplete. Currently, no efficient therapy is available for this disease, but recent data suggest that enzyme replacement therapy could be a valid option for the treatment of aceruloplasminemia [22,23].

Recombinant production of human CP would allow to exploit the power of sitedirected mutagenesis to clarify the molecular bases of functional impairment of aceruloplasminemia missense mutants, and it could also provide an answer to many open questions regarding the precise details of the catalytic mechanism of $\mathrm{CP}$ and of its interaction with ferroportin. Furthermore, recombinant human $\mathrm{CP}$ would represent a virtually unlimited source of protein available to test the validity of enzyme replacement therapy for treatment of aceruloplasminemia patients. Despite the fact that the coding sequence of human CP has been known since 1986 [24], a survey of the literature shows that, apart from our previous work on aceruloplasminemia mutants [20,25], only one paper published in 2001 reports expression and purification of limited amounts of recombinant human $\mathrm{CP}$, using the yeast Pichia pastoris as host [26]. All other papers dealing with the characterization of CP mutants employ transient transfection of mammalian cell lines for functional analyses and no purification of the recombinant protein is performed (e.g., $[21,27,28])$.

Here, we report production and preliminary characterization of high-quality recombinant human CP in glycoengineered Pichia pastoris. A modified yeast strain lacking the endogenous ferroxidase has been generated and employed as host for heterologous expression of the secreted isoform of human CP. Together with an improved purification procedure, this approach has allowed to obtain a biologically active protein with more homogeneous glycans.

\section{Results and Discussion}

Production of recombinant $\mathrm{CP}$ is extremely challenging due to the complexity of the protein: high $\mathrm{M}_{\mathrm{r}}$ (1046 amino acids for the mature secreted protein isoform), requirement for 6 copper atoms: three T1 plus a T2-T3 trinuclear cluster for enzymatic activity, Nglycosylation on multiple Asn residues, five disulfide bridges, sensitivity to proteases. We have previously reported the expression of secreted human CP in the yeast P. pastoris. However, the protein was only partially purified and it was heavily hyperglycosylated $[20,25]$.

Innovations to overcome the limitations of our former expression system take advantage of the development of new yeast strains and of improved components to tackle some of the problems associated with expression of secreted heterologous proteins. In particular, glycoengineered yeast strains afford control over glycan structure allowing the production of human-like $\mathrm{N}$-glycans. This is a significant improvement if use of the protein for therapeutic purposes is taken into consideration. 


\subsection{Expression of Recombinant $C P$}

Heterologous expression of the secreted isoform of human $\mathrm{CP}$ under control of the constitutive GAP promoter has been performed in the P. pastoris SM5 strain. This strain is engineered to produce GlcNAc2Man5 glycans by way of inactivation of the gene of the $\alpha-1,6$-mannosyltransferase Och1, and by constitutive overexpression of an ER-retained HDEL-tagged T. reesei $\alpha-1,2$-mannosidase [29,30]. Inactivation of OCH1 prevents addition of mannose residues on the GlcNAc2Man8 core, which is trimmed to GlcNAc2Man5 by T. reesei mannosidase [29]. Inactivation of the gene for the ferroxidase FET3 by the split marker strategy has been achieved in the SM5 strain, in order to avoid any possible background contamination with endogenous ferroxidase activity during expression of $\mathrm{CP}$. Two mutations have been introduced in the coding sequence of $\mathrm{CP}$ to replace Arg 481 and Lys887 with Gln to remove the two major sites responsible for the sensitivity of $\mathrm{CP}$ to proteolysis [31] (residue numbering is of the mature protein without the signal peptide). Furthermore, in the effort to improve secretion levels of the recombinant protein the native signal sequence of human $\mathrm{CP}$ has been replaced with a hybrid signal sequence derived from $S$. cerevisiae Ost1 and pro-alfa-factor, which directs co-translational translocation across the ER membrane [32]. Western blot analysis of culture supernatants from P. pastoris fet $3 \Delta$ strains expressing recombinant human $\mathrm{CP}$ either with the native or the modified signal sequence is shown in Figure 1.

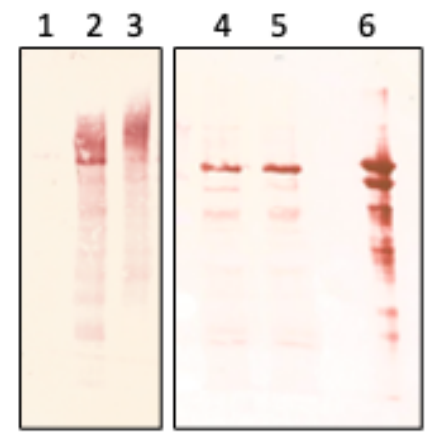

(a)

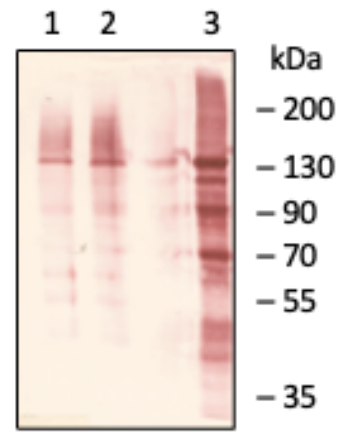

(b)

Figure 1. Western blot analysis of expression of recombinant human CP in P. pastoris. Panel (a): untransformed SM5 fet3 $\Delta$ (lane 1), CP expressed in fet3 $\Delta$ strains derived from SM5 (lane 2) or JC300 (lane 3); samples after treatment with EndoH are shown in lanes 4 (SM5) and 5 (JC300); lane 6, plasma-derived CP (200 ng). Panel (b): pOst1-alfaF-CP (lane 1) and CP with its native signal peptide (lane 2) expressed in SM5 fet3 $\Delta$. Lane 3, plasma-derived CP (200 ng). Yeast cells were grown to $\mathrm{OD}_{600}=2$ and culture supernatants were collected and concentrated 30 -fold; $20 \mu \mathrm{L}$ of concentrated culture supernatants was loaded on the gel.

Compared to JC300, expression levels of CP in glycoengineered SM5 were similar but a much more homogeneous protein with a band at the same $\mathrm{M}_{\mathrm{r}}$ of plasma-derived $\mathrm{CP}$ and a component with higher $\mathrm{M}_{\mathrm{r}}$ was produced (Figure 1a). Treatment with EndoH yielded a band with $\mathrm{M}_{\mathrm{r}}$ close to $120 \mathrm{kDa}$, indicating that the presence of N-glycans was responsible for the higher $\mathrm{M}_{\mathrm{r}}$ component of $\mathrm{CP}$. The yield of recombinant $\mathrm{CP}$ was not improved by replacement of the native signal sequence with the hybrid signal derived from Ost 1 and the pro-alfa-factor sequences [32] (Figure 1b). This finding suggests that co-translational translocation of the nascent polypeptide chain to the ER lumen is effective with the native signal sequence of $\mathrm{CP}$, confirming the ability of $P$. pastoris to correctly recognize and process mammalian signal peptides.

\subsection{Purification and Characterization of Recombinant $C P$}

Human CP with the native signal sequence has been produced in the SM 5 fet $3 \Delta$ strain grown in minimal medium supplemented with $\mathrm{CuSO}_{4}$ and $\mathrm{Fe}\left(\mathrm{NH}_{4}\right)_{2}\left(\mathrm{SO}_{4}\right)_{2}$. Highly pure recombinant $\mathrm{CP}$ has been obtained by a two-step chromatography procedure (Figure 2). 


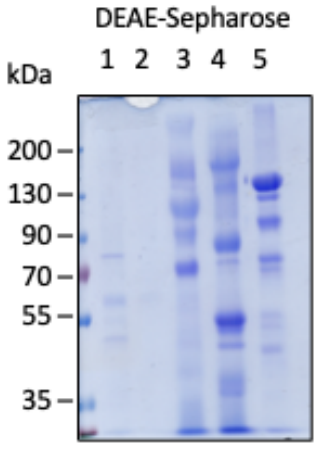

(a)

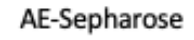

$\begin{array}{lllll}1 & 2 & 3 & 4 & 5\end{array}$

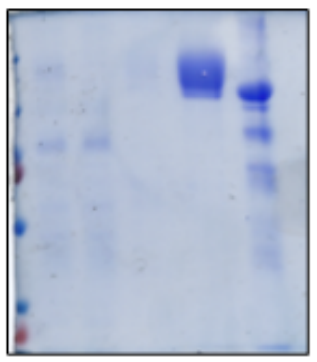

(b)

Figure 2. SDS-PAGE analysis of recombinant CP purified on DEAE-Sepharose (a) and AE-Sepharose (b). Panel (a): lane 1, input; lane 2, unbound fraction; lane 3, fraction eluted with $\mathrm{NaCl} 150 \mathrm{mM}$; lane 4, fraction eluted with $\mathrm{NaCl} 250 \mathrm{mM}$; lane 5, plasma-derived CP (5 $\mu \mathrm{g})$. Panel (b): lane 1, input; lane 2, unbound fraction; lane 3, fraction eluted with $\mathrm{NaCl} 250 \mathrm{mM}$; lane 4, fraction eluted with $\mathrm{NaCl}$ $500 \mathrm{mM}(8 \mu \mathrm{g})$; lane 5, plasma-derived CP $(5 \mu \mathrm{g})$.

A first anion exchange chromatography of culture supernatants on DEAE-Sepharose yielded a fraction eluted at $150 \mathrm{mM} \mathrm{NaCl}$ that was enriched in $\mathrm{CP}$ (Figure 2a). This fraction was further purified on AE-Sepharose, a chloroethylamine-derivatized Sepharose matrix with high affinity for $\mathrm{CP}[33,34]$. At variance with the hyperglycosylated recombinant protein produced in our previous work [20,25], CP bound strongly to AE-Sepharose and it was eluted at $500 \mathrm{mM} \mathrm{NaCl}$. SDS-PAGE analysis demonstrated that the protein had a high degree of purity, and no degradation was apparent. The recombinant $\mathrm{CP}$ exhibited a slightly higher $\mathrm{M}_{\mathrm{r}}$ compared to the plasma-derived protein (Figure $2 \mathrm{~b}$, lane 4 vs. lane 5). The yield of pure recombinant human $\mathrm{CP}$ was about $0.1 \mathrm{mg}$ from $1 \mathrm{~L}$ culture.

The enzymatic activity of purified recombinant human $\mathrm{CP}$ was assayed with $o$ dianisidine (oDA, a non-physiologic aromatic amine widely used to measure $\mathrm{CP}$ enzymatic activity) and iron as substrates. The specific oxidase activity towards oDA and the ferroxidase activity of recombinant $\mathrm{CP}$ was 90 and $96 \%$, respectively, of the plasma-derived $\mathrm{CP}$, indicating that the recombinant protein was fully active.

This result confirms that copper incorporation into recombinant $\mathrm{CP}$ has taken place correctly and that the yeast ATPase Ccc2, which delivers copper in the late Golgi or post-Golgi compartment $[25,35]$, is able to provide copper during biosynthesis of $\mathrm{CP}$ in P. pastoris SM5.

\subsection{Glycan Analysis of Recombinant CP}

To further investigate the source of the higher apparent molecular weight observed for recombinant $\mathrm{CP}$, deglycosylation with endoH was performed in non-denaturing conditions. SDS-PAGE analysis evidenced that after incubation with endoH the $\mathrm{M}_{\mathrm{r}}$ of the protein decreased to about $120 \mathrm{kDa}$, as expected for single-chain human CP (Figure 3). Non-denaturing SDS-PAGE and staining for oxidase activity with oDA confirmed that recombinant $\mathrm{CP}$ is enzymatically active also after removal of oligosaccharide chains. The electrophoretic mobility of the oxidase-active bands for recombinant $\mathrm{CP}$ is different from that of plasma-derived $\mathrm{CP}$ due to the different glycan moieties of the two proteins. It should be recalled that plasma-derived $\mathrm{CP}$ is resistant to endoH due to the complex nature of the glycan chains [20], so treatment with EndoH was not performed in this case. 


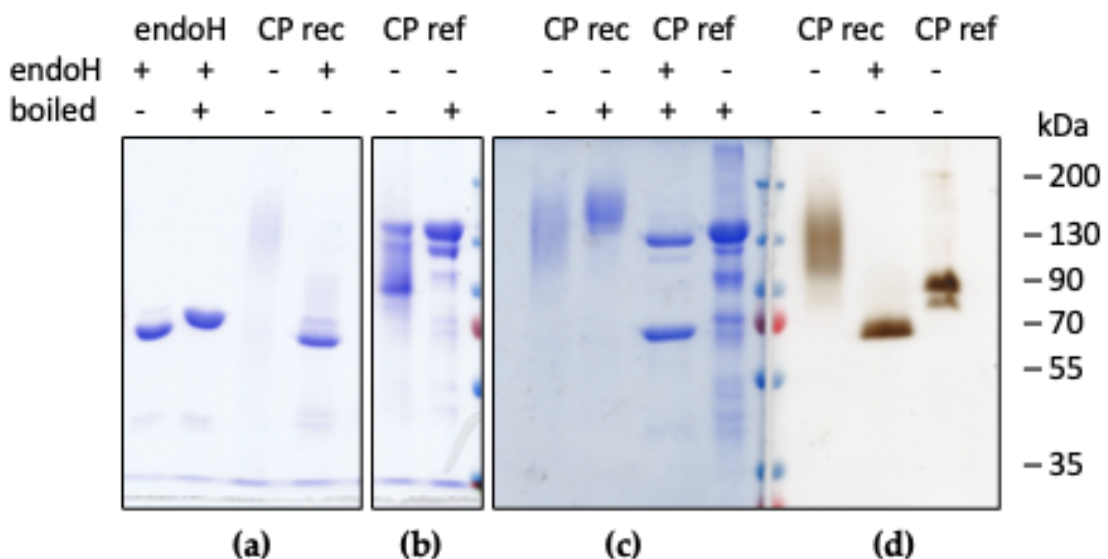

Figure 3. SDS-PAGE analysis of purified recombinant $\mathrm{CP}$ before and after treatment with endoH. Recombinant CP was incubated with EndoH in non-denaturing conditions. Samples of recombinant $\mathrm{CP}(\mathrm{CP}$ rec, $1 \mu \mathrm{g}$ in panel (a), $3 \mu \mathrm{g}$ in panels $(\mathbf{b}-\mathbf{d})$ ) and of plasma-derived CP (CP ref, $5 \mu \mathrm{g}$ ) were loaded with or without heat treatment as indicated. EndoH is shown in the first two lanes. Panels $(\mathbf{a}-\mathbf{c})$ : Coomassie staining; panel (d): oxidase activity staining with oDA.

The amino acid sequence of human $\mathrm{CP}$ contains 7 potential $\mathrm{N}$-glycosylation sites: Asn119, Asn339, Asn378 and Asn743 (which are modified by addition of complex oligosaccharide chains in plasma-derived CP) and Asn208, Asn569 and Asn907 (which are not occupied in the native protein) $[31,36]$. Glycan analysis has been performed on purified recombinant $\mathrm{CP}$ in order to determine glycan structure and occupancy at the different sites (Tables 1 and 2, and Figure 4). Table 1 reports the main N-glycoforms (above $6 \%$ relative intensity) detected by MALDI TOF of permethylated N-glycans released from recombinant CP. Although SM5 is engineered to produce HexNAc2Hex5 structures, the two most abundant species were high-mannose HexNAc2Hex8 and HexNAc2Hex11. Off-target unexpected N-glycan structures have been detected in other proteins expressed in SM5, indicating that this is probably a common problem encountered with glycoengineered P. pastoris strains [37]. The dominating structures of these N-glycans were variable and appeared to be somewhat protein-dependent [37].

Table 1. Main N-glycoforms detected in recombinant human CP.

\begin{tabular}{cccc}
\hline Structure & $\boldsymbol{m} / \boldsymbol{z}$ (Permethylated) & Intensity & $\begin{array}{c}\text { Relative Intensity } \\
\text { (\%) }\end{array}$ \\
\hline HexNAc2Hex5 & 1579.971 & 764 & 6.1 \\
HexNAc2Hex7 & 1988.437 & 1199 & 9.5 \\
HexNAc2Hex8 & 2192.73 & 2211 & 17.6 \\
HexNAc2Hex9 & 2397.024 & 1045 & 8.3 \\
HexNAc2Hex10 & 2601.325 & 1443 & 11.5 \\
HexNAc2Hex11 & 2805.58 & 1821 & 14.5 \\
HexNAc2Hex12 & 3009.771 & 969 & 7.7 \\
\hline
\end{tabular}


Table 2. Occupancy of glycosylation sites of CP determined by enzymatic ${ }^{18} \mathrm{O}$ deamidation after PNGase F digest.

\begin{tabular}{|c|c|c|c|}
\hline N-Glycosylation Site ${ }^{1}$ & Covered by Peptides & $\begin{array}{c}\text { Ratio }^{18} \mathrm{O} \text {-Asp/Asn } \\
\text { after PNGase } F^{3}\end{array}$ & $\begin{array}{c}\% \text { of } \\
\text { Glycosylation }\end{array}$ \\
\hline Asn119* & Yes & 0.61012 & 38 \\
\hline Asn208 & $\mathrm{No}^{2}$ & - & - \\
\hline Asn339* & Yes & ND & ND \\
\hline Asn $378 *$ & Yes & 6.2394 & 86 \\
\hline Asn569 & Yes & ND & ND \\
\hline Asn743* & Yes & 2.2496 & 69 \\
\hline Asn907 & Yes & ND & ND \\
\hline
\end{tabular}

${ }^{1}$ Numbering is of the mature protein without the signal peptide; N-glycosylation sites occupied in the native CP are marked with an asterisk $\left({ }^{*}\right) .{ }^{2}$ Neither peptides nor glycopeptides bearing Asn208 N-glycosylation site were observed. ${ }^{3}$ Calculation of overall occupancy of respective glycosite based on peptide intensities bearing ${ }^{18} \mathrm{O}$-Asp and Asn.

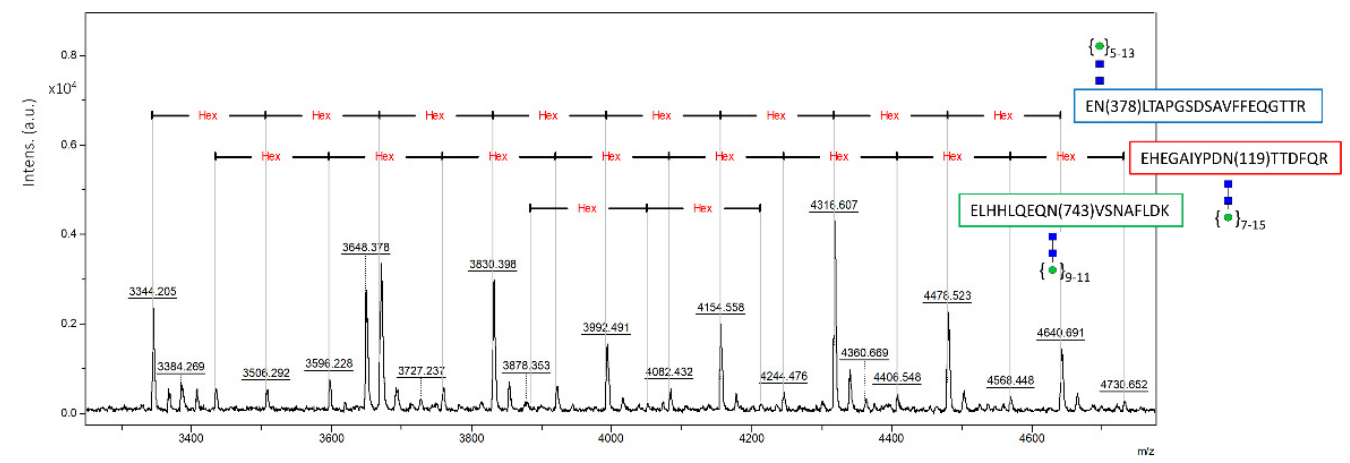

Figure 4. MALDI TOF spectrum of recombinant CP tryptic glycopeptides including their peptide backbones and glycans attached.

Determination of glycosite occupancy was performed by analysis of tryptic glycopeptides after their enrichment by HILIC SPE (Figure 4). The three N-glycosylation sites at Asn119, Asn378 and Asn743 were detected as occupied by high-mannose N-glycans predominantly of HexNAc2Hex7-8-9-11 structure. No glycopeptides bearing the Asn339 site were observed. N-glycan chains are missing at the Asn339 site in isoform II of human plasma-derived $\mathrm{CP}$, that represents a minor form of the circulating protein [31], suggesting that this site may be less accessible for modification.

Extent of occupancy of the individual glycosylation sites was evaluated by their stable isotope labelling. In the process of enzymatic N-glycan cleavage by PNGase F hydrolase, asparagine residues with attached glycan are converted to aspartate. In the environment of ${ }^{18} \mathrm{O}$-water, created ${ }^{18} \mathrm{O}$-Asp indicates the presence of a glycosylation site that is observed by a mass shift in the subsequent proteomic analysis by nanoLC-MS/MS In addition, enzymatic stable isotope labelling helps to distinguish the true glycosylation sites from a spontaneous Asn deamidation that may occur during the protein purification and storage. The presence of peptides with the original Asn indicates lack of glycosylation at the corresponding site. Based on this approach, glycosylation was confirmed at Asn119, Asn378, and Asn743. The glycosylation site at Asn339 was confirmed to be unoccupied by glycans as it was reported only as Asn (Table 2). High occupancy of $86 \%$ and $69 \%$ was found at Asn378 and Asn743, respectively. Instead, Asn119 appeared to be modified to a lower extent (38\%). Thus, results obtained from analysis of occupancy of glycosylation sites suggest that three out of four glycosites, occupied in plasma-derived $\mathrm{CP}$, were also present in analyzed recombinant CP. Original data from proteomic analysis of recombinant $\mathrm{CP}$ and its glycosylation sites is available as Supplementary Materials. 


\section{Materials and Methods}

\subsection{Yeast Strains}

The glycoengineered Pichia pastoris SuperMan5 (och1 1 1, GAP-mannosidaseHDEL, his4 $\Delta 1$ ) strain (SM5) was purchased from BioGrammatics (Carlsbad, CA, USA). The original fet $3 \Delta$ strain derived from JC300 (ade1, arg4, his4) is described in [25]. Yeast cells were grown at $30{ }^{\circ} \mathrm{C}$ in YPD or in MD minimal medium with the appropriate auxotrophic supplements. Inactivation of the endogenous ferroxidase FET3 gene in SM5 was achieved by the split marker strategy. Briefly, a KanR marker expression cassette including KanR flanked by the GAP promoter and AOX1 terminator was amplified from pIB2KAN and it was inserted in pBS-FET3 [25] following digestion with BamHI to replace $335 \mathrm{bp}$ of FET3 coding sequence. The cassette was split by digestion with $\mathrm{KpnI} / \mathrm{SspI}$ and ClaI/BglII to produce two fragments, including about $600 \mathrm{bp}$ of FET3 sequence and about $800 \mathrm{bp}$ of KanR sequence each, with a 240 bp overlap. Electroporation of SM5 cells was performed with the two overlapping DNA fragments and cells were plated on YPD supplemented with $0.5 \mathrm{mg} / \mathrm{mL}$ G418. To screen for the inactivation of FET3, G418-resistant colonies were plated on MDH with or without the iron chelator BPS $20 \mu \mathrm{M}$, and after $48 \mathrm{~h}$ at $30^{\circ} \mathrm{C}$ they were scored for lack of growth. Colonies with impaired growth in BPS were further screened by PCR on genomic DNA and lack of Fet3p oxidase activity to confirm inactivation of the FET3 gene. Genomic DNA was extracted according to [38] and PCR was carried out with the following primers: fet3_forward $5^{\prime}$-aggaattcatgtttgtattcgaacc- $3^{\prime}$; kan_reverse $5^{\prime}$-gacctcgagttagaaaaactcatcgagcatc- $3^{\prime}$ with the following conditions: $95^{\circ} \mathrm{C}$ for 5 min followed by 25 cycles $95^{\circ} \mathrm{C} 30 \mathrm{~s}, 58^{\circ} \mathrm{C} 30 \mathrm{~s}, 72{ }^{\circ} \mathrm{C} 2 \mathrm{~min} 30 \mathrm{~s}$ and a final extension at $72{ }^{\circ} \mathrm{C}$ for $5 \mathrm{~min}$.

\subsection{Expression and Purification of Recombinant $C P$}

The plasmid for constitutive expression of the secreted isoform of human $\mathrm{CP}$ is described in $[20,25]$. Site-directed mutagenesis by overlap extension PCR was performed to replace Arg481 and Lys887 with Gln in order to remove the two major sites responsible for susceptibility of $\mathrm{CP}$ to proteolysis [28]. A version of $\mathrm{CP}$ with the native signal peptide replaced with a hybrid Ost1/alfa-factor signal peptide described in [32] was produced by PCR and cloned in the same vector for constitutive expression as wild type CP. The pPICZpOst1-pro-alfaF(MUT1)-E2-Crimson from which the hybrid signal peptide was amplified was a gift from B.S. Glick (Addgene plasmid \#117662). All plasmids were linearized with SalI and electroporated in the SM5 fet $3 \Delta$ strain. The presence of the CP coding sequence was confirmed by PCR on genomic DNA of selected $\mathrm{His}^{+}$colonies.

Expression of secreted CP was performed in MD buffered with $50 \mathrm{mM}$ potassium phosphate $\mathrm{pH} 6.8$ supplemented with $\mathrm{CuSO}_{4} 50 \mu \mathrm{M}$ and $\mathrm{Fe}\left(\mathrm{NH}_{4}\right)_{2}\left(\mathrm{SO}_{4}\right)_{2} 50 \mu \mathrm{M}$. For smallscale analysis, $10-\mathrm{mL}$ cultures were employed and culture supernatants were concentrated 30-fold with Millipore Ultra $30 \mathrm{~K}$ devices. One-litre cultures were used for purification of the protein. Supernatants from overnight cultures were filtered, diluted 1:3, brought to pH 7.1 and loaded onto DEAE-Sepharose ( $7.5 \mathrm{~mL}$ resin for 11 culture medium) in $25 \mathrm{mM}$ Mops buffer pH 7.0, supplemented with $30 \mathrm{mM} \mathrm{NaCl}$. The resin was washed with the same buffer (10 column volumes) and CP was eluted with $25 \mathrm{mM}$ Mops $\mathrm{pH}$ 7.0, containing $150-250 \mathrm{mM} \mathrm{NaCl}$ (4 column volumes). The CP-containing fraction was diluted 1:3 and loaded onto $1 \mathrm{~mL}$ Sepharose derivatized with chloroethylamine (AE-Sepharose) [33] in $25 \mathrm{mM}$ Mops pH 7.0, containing $50 \mathrm{mM} \mathrm{NaCl}$. The resin was washed with the same buffer (10 column volumes) and CP was eluted with $25 \mathrm{mM}$ Mops $\mathrm{pH}$ 7.0, containing $250-500 \mathrm{mM}$ $\mathrm{NaCl}$ (5 column volumes). CP-containing fractions were concentrated with Millipore Ultra 30K devices.

\subsection{Characterization of Recombinant CP}

Denaturing and non-denaturing SDS-PAGE and staining for oxidase activity with $o$-dianisidine were performed as described [20]. Western blot was performed with rabbit polyclonal anti-CP antibody (Dako) at 1:5000 dilution. Total protein content was evaluated 
by the Bradford assay (BioRad) using BSA as a standard. Deglycosylation with EndoH $_{\mathrm{f}}$ (NEB) was performed in non-denaturing conditions for $1 \mathrm{~h}$ at $37^{\circ} \mathrm{C}$.

Oxidase activity was determined with $1.58 \mathrm{mM}$ o-dianisidine (oDA) in $0.5 \mathrm{~mL} 100 \mathrm{mM}$ sodium acetate buffer $\mathrm{pH} 6.0$ for $1 \mathrm{~h}$ at $37^{\circ} \mathrm{C}$. The reaction was stopped with $0.5 \mathrm{~mL}$ of $9 \mathrm{M}$ $\mathrm{H}_{2} \mathrm{SO}_{4}$ and the amount of product was determined by absorbance at $540 \mathrm{~nm}$. Ferroxidase activity of $\mathrm{CP}$ was assayed with $20-100 \mu \mathrm{M} F e\left(\mathrm{NH}_{4}\right)_{2}\left(\mathrm{SO}_{4}\right)_{2}$ in $100 \mathrm{mM}$ sodium acetate buffer $\mathrm{pH} 6.0$ at $25^{\circ} \mathrm{C}$ for $5-10 \mathrm{~min}$. The amount of residual $\mathrm{Fe}^{2+}$ was measured by the addition of $1 \mathrm{mM}$ ferrozine and determination of absorbance at $562 \mathrm{~nm}\left(\varepsilon_{562} 27,900 \mathrm{M}^{-1} \mathrm{~cm}^{-1}\right)$. Plasma-derived CP was purified by the single-step procedure described in [33]. The protein showed a $610 / 280$ ratio $>0.04$.

\subsection{Glycan Analysis}

\subsubsection{Analysis of N-Glycoprofile}

Analysis of N-glycans was performed as described before [39]. Briefly, after the release of N-glycans with PNGase F (Roche), the sample was subjected to PGC chromatography. $\mathrm{N}$-glycans were eluted, permethylated and analyzed by MALDI TOF in reflectron positive ion mode with the UltrafleXtreme MALDI mass spectrometer (Bruker Daltonics, Billerica, MA, USA).

\subsubsection{Analysis of N-Glycopeptides and Occupancy of Glycosylation Sites}

Tryptic peptides bearing N-glycans were analyzed by MALDI TOF. Occupancy of glycosylation sites was determined by hydrolytic labelling of occupied Asn residues that were deamidated to ${ }^{18} \mathrm{O}$-Asp by nanoLC-MS/MS using Orbitrap Elite mass spectrometer (Thermo Fisher Scientific, Waltham, MA, USA). Full details of glycan and glycopeptide analysis are described in the Supplementary Materials.

\section{Conclusions}

If compared to the yields that can be obtained by the isolation of $\mathrm{CP}$ from human plasma where the concentration of the protein is about $300 \mathrm{mg} / \mathrm{L}$, it is evident that there is no advantage in heterologous expression, where production levels are much lower. In fact, $\mathrm{CP}$ appears to be one of those cases where the natural source provides much more protein than the recombinant expression system. However, the availability of high-quality recombinant protein represents a significant advancement in the field of $\mathrm{CP}$ biology because it makes it feasible to design and produce site-specific mutants of CP. This breakthrough is crucial for studies aimed at unveiling the molecular basis of defective missense aceruloplasminemia mutants. Moreover, specifically designed mutants based on the available 3D structure of human $\mathrm{CP}$ will allow to define the details of the catalytic activity and of the molecular interaction of the ferroxidase with ferroportin.

On a different note, productivity would need to be greatly increased and, more importantly, the finding that HexNAc2Hex8 and HexNAc2Hex11 glycan chains are predominant in recombinant $\mathrm{CP}$ indicates that the glycan structure is probably unsuitable and further careful glycoengineering of the SM5 strain will be mandatory before any potential therapeutic use of the recombinant protein for enzyme replacement therapy of aceruloplasminemia patients can be envisaged.

Supplementary Materials: The following are available online at https://www.mdpi.com/article/10 $.3390 /$ ijms22158228/s1, Supplementary methods with figures and data.

Author Contributions: Conceptualization, M.C.B.d.P. and G.M.; methodology, M.C.B.d.P., M.N., Z.P. and P.B.; investigation, M.C.B.d.P., A.C., M.N., Z.P. and P.B.; data curation, M.N., Z.P. and P.B.; writing—original draft preparation, M.C.B.d.P.; writing—review and editing, M.C.B.d.P.; G.M.; visualization, M.C.B.d.P., A.C., M.N., Z.P., P.B. and G.M. All authors have read and agreed to the published version of the manuscript.

Funding: This research was performed with the support of the Operational Program Integrated Infrastructure for the project: Center for Biomedical Research-BIOMEDIRES-II. Stage, ITMS: 
313011W428, co-financed by the European Regional Development Fund (P.B.); grants from Ministry of Health of the Slovak Republic under the project registration number 2019/7-CHÚSAV-4 (Z.P.), VEGA 2/0060/2 (M.N.) and grants from Sapienza University of Rome-Progetti di Ateneo (M.C.B.d.P.).

Data Availability Statement: All data are reported in the manuscript and Supplementary Materials.

Acknowledgments: Support by Instruct-ERIC through the Glycan Analysis Open Call (APPID 1429) is gratefully acknowledged (M.C.B.d.P.).

Conflicts of Interest: The authors declare no conflict of interest. The funders had no role in the design of the study; in the collection, analyses, or interpretation of data; in the writing of the manuscript, or in the decision to publish the results.

\section{References}

1. Solomon, E.I.; Sundaram, U.; Machonkin, T.E. Multicopper oxidases and oxygenases. Chem. Rev. 1996, 96, 2563-2606. [CrossRef]

2. Kosman, D.J. Multicopper oxidases: A workshop on copper coordination chemistry, electron transfer, and metallophysiology. J. Biol. Inorg. Chem. 2010, 15, 15-28. [CrossRef]

3. Musci, G.; Polticelli, F.; Bonaccorsi di Patti, M.C. Ceruloplasmin-ferroportin system of iron traffic in vertebrates. World J. Biol. Chem. 2014, 5, 204-215.

4. Vasilyev, V.B. Looking for a partner: Ceruloplasmin in protein-protein interactions. Biometals 2019, 32, 195-210. [CrossRef]

5. Pietrangelo, A. Ferroportin disease: Pathogenesis, diagnosis and treatment. Haematologica 2017, 102, 1972-1984. [CrossRef] [PubMed]

6. Vlasveld, L.T.; Janssen, R.; Bardou-Jacquet, E.; Venselaar, H.; Hamdi-Roze, H.; Drakesmith, H.; Swinkels, D.W. Twenty years of ferroportin disease: A review or an update of published clinical, biochemical, molecular, and functional features. Pharmaceuticals 2019, 12, 132. [CrossRef] [PubMed]

7. Rishi, G.; Subramaniam, N.V. Biology of the iron efflux transporter, ferroportin. Adv. Prot. Chem. Struct. Biol. 2021, $123,1-16$.

8. Vulpe, C.D.; Kuo, Y.M.; Murphy, T.L.; Cowley, L.; Askwith, C.; Libina, N.; Gitschier, J.; Anderson, G.J. Hephaestin, a ceruloplasmin homologue implicated in intestinal iron transport, is defective in the sla mouse. Nat. Genet. 1999, 21, 195-199. [CrossRef]

9. Ji, C.; Steimle, B.L.; Bailey, D.K.; Kosman, D.J. The ferroxidase hephaestin but not amyloid precursor protein is required for ferroportin-supported iron efflux in primary hippocampal neurons. Cell. Mol. Neurobiol. 2018, 38, 941-954. [CrossRef]

10. De Domenico, I.; McVey Ward, D.; Bonaccorsi di Patti, M.C.; Jeong, S.Y.; David, S.; Musci, G.; Kaplan, J. Ferroxidase activity is required for the stability of cell surface ferroportin in cells expressing GPI-ceruloplasmin. EMBO J. 2007, 26, 2823-2831. [CrossRef]

11. Dlouhy, A.C.; Bailey, D.K.; Steimle, B.L.; Parker, H.V.; Kosman, D.J. Fluorescence resonance energy transfer links membrane ferroportin, hephaestin but not ferroportin, amyloid precursor protein complex with iron efflux. J. Biol. Chem. 2019, 294, 4202-4214. [CrossRef]

12. Harris, Z.L.; Takahashi, Y.; Miyajima, H.; Serizawa, M.; McGillivray, R.T.; Gitlin, J.D. Aceruloplasminemia: Molecular characterization of this disorder of iron metabolism. Proc. Natl. Acad. Sci. USA 1995, 92, 2539-2543. [CrossRef] [PubMed]

13. Yoshida, K.; Furihata, K.; Takeda, S.; Nakamura, A.; Yamamoto, K.; Morita, H.; Hiyamuta, S.; Ikeda, S.; Shimizu, N.; Yanagisawa, N. A mutation in the ceruloplasmin gene is associated with systemic hemosiderosis in humans. Nat. Genet. 1995, 9, 267-272. [CrossRef]

14. Kono, S. Aceruloplasminemia. Curr. Drug Targ. 2012, 13, 1190-1199. [CrossRef] [PubMed]

15. McNeill, A.; Pandolfo, M.; Kuhn, J.; Shang, H.; Miyajima, H. The neurological presentation of ceruloplasmin gene mutations. Eur. Neurol. 2008, 60, 200-205. [CrossRef] [PubMed]

16. Vila Cuenca, M.; Marchi, G.; Barqué, A.; Esteban-Jurado, C.; Marchetto, A.; Giorgetti, A.; Chelban, V.; Houlden, H.; Wood, N.W.; Piubelli, C.; et al. Genetic and clinical heterogeneity in thirteen new cases with aceruloplasminemia. Atypical anemia as a clue for an early diagnosis. Int. J. Mol. Sci. 2020, 21, 2374. [CrossRef] [PubMed]

17. Miyajima, H. Aceruloplasminemia. Neuropathology 2015, 35, 83-90. [CrossRef]

18. Hellman, N.E.; Kono, S.; Miyajima, H.; Gitlin, J.D. Biochemical analysis of a missense mutation in aceruloplasminemia. J. Biol. Chem. 2002, 277, 1375-1380. [CrossRef]

19. Kono, S.; Miyajima, H. Molecular and pathological basis of aceruloplasminemia. Biol. Res. 2006, 39, 15-23. [CrossRef]

20. Bonaccorsi di Patti, M.C.; Maio, N.; Rizzo, G.; De Francesco, G.; Persichini, T.; Colasanti, M.; Polticelli, F.; Musci, G. Dominant mutants of ceruloplasmin impair the copper loading machinery in aceruloplasminemia. J. Biol. Chem. 2009, 284, $4545-4554$. [CrossRef]

21. Kono, S.; Yoshida, K.; Tomosugi, N.; Terada, T.; Hamaya, Y.; Kanaoka, S.; Miyajima, H. Biological effects of mutant ceruloplasmin on hepcidin-mediated internalization of ferroportin. Biochim. Biophys. Acta 2010, 1802, 968-975. [CrossRef]

22. Piperno, A.; Alessio, M. Aceruloplasminemia: Waiting for an efficient therapy. Front. Neurosci. 2018, 12, 903. [CrossRef] [PubMed]

23. Zanardi, A.; Conti, A.; Cremonesi, M.; D’Adamo, P.; Gilberti, E.; Apostoli, P.; Cannistraci, C.V.; Piperno, A.; David, S.; Alessio, M. Ceruloplasmin replacement therapy ameliorates neurological symptoms in a preclinical model of aceruloplasminemia. EMBO Mol. Med. 2018, 10, 91-106. [CrossRef] [PubMed] 
24. Yang, F.; Naylor, S.L.; Lum, J.B.; Cutshaw, S.; McCombs, J.L.; Naberhaus, K.H.; McGill, J.R.; Adrian, G.S.; Moore, C.M.; Barnett, D.R.; et al. Characterization, mapping, and expression of the human ceruloplasmin gene. Proc. Natl. Acad. Sci. USA 1986, 83, 3257-3261. [CrossRef] [PubMed]

25. Maio, N.; Polticelli, F.; De Francesco, G.; Rizzo, G.; Bonaccorsi di Patti, M.C.; Musci, G. Role of external loops of human ceruloplasmin in copper loading by ATP7B and Ccc2p. J. Biol. Chem. 2010, 285, 20507-20513. [CrossRef] [PubMed]

26. Bielli, P.; Bellenchi, G.C.; Calabrese, L. Site-directed mutagenesis of human ceruloplasmin: Production of a proteolytically stable protein and structure-activity relationships of type 1 sites. J. Biol. Chem. 2001, 276, 2678-2685. [CrossRef]

27. Brown, M.A.; Stenberg, L.M.; Mauk, A.G. Identification of catalytically important amino acids in human ceruloplasmin by site-directed mutagenesis. FEBS Lett. 2002, 520, 8-12. [CrossRef]

28. Hellman, N.E.; Kono, S.; Mancini, G.M.; Hoogeboom, A.J.; de Jong, G.J.; Gitlin, J.D. Mechanisms of copper incorporation into human ceruloplasmin. J. Biol. Chem. 2002, 277, 46632-46638. [CrossRef]

29. Vervecken, W.; Kaigorodov, V.; Callewaert, N.; Geysens, S.; De Vusser, K.; Contreras, R. In vivo synthesis of mammalian-like, hybrid-type N-glycans in Pichia pastoris. Appl. Environ. Microbiol. 2004, 70, 2639-2646. [CrossRef] [PubMed]

30. Jacobs, P.P.; Geysens, S.; Vervecken, W.; Contreras, R.; Callewaert, N. Engineering complex N-type glycosylation in Pichia pastoris using GlycoSwitch technology. Nat. Protoc. 2009, 4, 58-70. [CrossRef] [PubMed]

31. Takahashi, N.; Ortel, L.T.; Putnam, W.F. Single-chain structure of human ceruloplasmin: The complete amino acid sequence of the whole molecule. Proc. Natl. Acad. Sci. USA 1984, 81, 390-394. [CrossRef]

32. Barrero, J.J.; Casler, J.C.; Valero, F.; Ferrer, P.; Glick, B.S. An improved secretion signal enhances the secretion of model proteins from Pichia pastoris. Microb. Cell Fact. 2018, 17, 161. [CrossRef] [PubMed]

33. Musci, G.; Bonaccorsi di Patti, M.C.; Fagiolo, U.; Calabrese, L. Age-related changes in human ceruloplasmin. Evidence for oxidative modifications. J. Biol. Chem. 1993, 268, 13388-13395. [CrossRef]

34. Stern, R.V.; Caffrey, J.M.; Frieden, E. A tentacle gel simplifies the purification of ceruloplasmin. Biochem. Int. 1992, 27, 281-289.

35. Yuan, D.S.; Dancis, A.; Klausner, R.D. Restriction of copper export in Saccharomyces cerevisiae to a late Golgi or post-Golgi compartment in the secretory pathway. J. Biol. Chem. 1997, 272, 25787-25793. [CrossRef] [PubMed]

36. Baerenfaenger, M.; Moritz, M.; Meyer, B. Quantitation of glycopeptides by ESI/MS—Size of the peptide part strongly affects the relative proportions and allows discovery of new glycan compositions of ceruloplasmin. Glycoconj. J. 2019, 36, 13-26. [CrossRef] [PubMed]

37. Laukens, B.; Jacobs, P.P.; Geysens, K.; Martins, J.; De Wacther, C.; Ameloot, P.; Morelle, W.; Haustraete, J.; Renauld, J.C.; Samyn, B.; et al. Off-target glycans encountered along the synthetic biology route toward humanized N-glycans in Pichia pastoris. Biotechnol. Bioeng. 2020, 117, 2479-2488. [CrossRef]

38. Looke, M.; Kristjuhan, K.; Kristjuhan, A. Extraction of genomic DNA from yeasts for PCR-based applications. Biotechniques 2011, 50, 325-328. [CrossRef]

39. Pažitná, L.; Nemčovič, M.; Pakanová, Z.; Baráth, P.; Aliev, T.; Dolgikh, D.; Argentova, V.; Katrlík, J. Influence of media composition on recombinant monoclonal IgA1 glycosylation analysed by lectin-based protein microarray and MALDI-MS. J. Biotechnol. 2020, 314-315, 34-40. [CrossRef] 